\title{
A QUEDA OU O SALTO PARA O ALTO o religioso na ficção de Jorge de Lima William Cereja
}

Resumo Examinando as obras da prosa de ficção de Jorge de Lima, este ensaio busca identificar o fio condutor que as atravessa e liga como parte significativa do projeto estético do escritor alagoano. Além disso, busca estabelecer relaçōes entre essas obras e o grupo católico carioca, particularmente com as idéias essencialistas de Ismael Nery. Palavras-chave queda, cristianismo, neotomismo, essencialismo.

Abstract By examining Jorge de Lima's fictional prose works, this paper intends to identify the guidelines that conduct and connect them as a significant part of the poet's aesthetic project. It intends as well to establish connections between these works and those of the Catholic literary group from Rio de Janeiro, mainly Ismael Nery's essentialist ideas. Keywords fall, Christianism, neo-thomism, essentialism. 
I O professor Alexandre

Eulálio comenta: "Ines-

perada conversão ao $\mathrm{Ca}$ tolicismo, que tem lugar em I926, culmina essa agonia. A crise dissimulada mal e mal já estava transparecendo nos textos compósitos que divulga e projeta no decênio de 20 . $O$ caso de Comédia dos erros, obra em parte ensaística, em parte ficcional, impressa em 1923 mas recolhendo escritos de anos antes, conforme alusões ao 'recente' centenário de Wagner indicam. O caso ainda da temática do romance que começa a compor em 1922, Cipó de Imbé, que trata da fluida identidade do intelectual brasileiro, instável e sem norte - obra que, com modificações de monta, o autor editaria em 1927, agora com 0 título Salomão e as mutheres - até mais uma vez estabilizar o texto, agora em clave líricopsicologizante-metafísica, na terceira versão que urde desse texto,
A arte seria revelação, o artista receptáculo dessa revelação. $O$ artista é apenas um colaborador na magia de que é o oficiante, na tragédia sagrada de que é cúmplice. [Jorge de Lima]

\section{O Anjo: uma tela e seus esboços}

Jorge de Lima escreveu quatro obras de ficção: O Anjo (1934), Calunga (I935), A mulher obscura (1939) e Guerra dentro do beco (I950). A mulher obscura é a terceira e última versão de uma obra que teve duas edições anteriores, a primeira em i922, com o título de Cipó de Imbé, e a segunda em I927, com o título Salomão e as mulheres.

Consideradas no conjunto, essas obras refletem os rumos tomados pela ficção brasileira na primeira metade do século xx, isto é, a superação da tradição passadista, o experimentalismo estético, o regionalismo, o engajamento. O Anjo, por exemplo, herda fortes influências do experimentalismo brasileiro dos anos 20 , inclusive com nítida intenção surrealista, ao mesmo tempo que apresenta certos aspectos constitutivos da prosa de ficção da década de 30, como o regionalismo e as preocupações de ordem espiritual e religiosa.

Já Calunga é a obra do conjunto que mais se identifica com a orientação regionalista da ficção de 30, fazendo abertamente uma denúncia contra as estruturas latifundiárias nordestinas, o coronelismo e as condições subumanas dos trabalhadores da região, engrossando o coro entoado por obras como Vidas secas, São Bernardo, O Quinze, Seara vermelha e outras. Contudo, diferentemente dessas obras e a despeito de seu enfoque realista, Calunga remete ao universo mítico-cristão.

A mulher obscura retoma o caminho da representação alegórica iniciado em $O$ Anjo e, com um enfoque nitidamente católico, visa tratar da precariedade da condição humana, da suposta queda edênica aos dias de hoje.

Guerra dentro do beco, no rastro do romance anterior, atualiza o enfoque, situando-o no contexto da Segunda Guerra Mundial e no universo de idéias e conflitos que envolveram artistas e intelectuais dos anos 40. As idéias religiosas têm espaço assegurado, dando continuidade e fechamento ao ideário mítico-religioso iniciado em $O$ Anjo.

Trata-se, portanto, de um grupo de obras que têm lugar no arcabouço das idéias, intenções e procedimentos do romance de 30. Talvez elas sejam, inclusive, a principal realização em prosa do grupo católico carioca, que contou tam- 
bém com as obras de Octávio Faria, entre as quais se inclui Tragédia burguesa. E é justamente a confluência de uma pluralidade de correntes e perspectivas, em princípio excludentes, como o Surrealismo, o pensamento católico neotomista e o regionalismo, que confere singularidade à ficção de Jorge de Lima.

Ao fazermos uma leitura vertical das obras que compõem essa ficção, notamos que elas apresentam vários aspectos em comum, como a estruturação de personagens, a oposição entre o meio rural e o urbano, o ideal feminino e amoroso, a religiosidade e a recorrência de algumas imagens arquetípicas relacionadas à queda. Pode-se até supor que $O$ Anjo seja uma espécie de célula-mãe das outras, em virtude de certas posturas e temas retomados posteriormente.

As experiências do autor com A mulher obscura permitem-nos associar a escritura de suas obras em prosa com suas experiências no campo da pintura. Como um pintor que faz vários esboços antes de chegar à forma definitiva de um quadro, assim parecia proceder Jorge de Lima quando escrevia ficção. Talvez pelo fato de a ficção geralmente demandar maior fôlego e tempo de elaboração do que o poema, ou pelo fato de exigir certo tipo de planejamento, o certo é que as formas encontradas por Jorge de Lima em sua experiência na ficção pareciam nunca estar concluídas.

Bem ao gosto das experiências formais do primeiro tempo modernista, também são comuns as transposições de parte da prosa de Jorge de Lima para a poesia, ou o contrário. Em $O$ Anjo, por exemplo, encontramos na forma de prosa poética o poema "Felicidade" publicado dois anos antes. O mesmo ocorre com o livro Poemas negros (I947), que apresenta um poema em prosa, "Zefa Lavadeira", transposição direta de um fragmento de A mulher obscura.

Considerada a hipótese de $O$ Anjo ser uma espécie de referência e guia para as obras publicadas posteriormente, Calunga seria, do conjunto, a que mais claramente apresenta pontos de contato com aquela obra. Convém lembrar a data de publicação de ambas: 1934 e I935, respectivamente. Assim, é provável que Jorge de Lima revisava as provas de $O$ Anjo enquanto escrevia as primeiras versões de Calunga, o que explica em grande parte um conjunto de aspectos comuns entre elas. ${ }^{2}$

Eis alguns desses aspectos: o retorno do "filho pródigo" à sua terra natal, depois de ter vivido anos na cidade; o contraste entre o rude homem nativo e o homem estudado, que vive na capital; a denúncia das precárias condições de vida do homem nordestino que se alimenta do sururu das lagoas Manguaba e Mundaú, em Alagoas; as reflexões filosófico-cristãs sobre a condição humana, com inúmeras alusões bíblicas, particularmente as sugeridas pelo barro; o que agora, I939, aparece com o título tematizado como A mulher obscura. Folha de São Paulo, Sāo Paulo, 20.II.I983. Folhetim, no 357 .

2 Embora esta não seja uma questão essencial neste estudo, vale lembrar que há opiniões diferentes sobre o processo de criação dessas obras. Antônio Rangel Bandeira, em Jorge de Lima: o roteiro de uma contradição (Rio de Janeiro: Livraria São José, I959, p. 72) defende a tese de que Calunga foi escrito antes de $O$ Anjo. Povina Cavalcanti, cunhado do autor, discorda dessa opinião: acha que as duas obras foram concebidas de uma vez: "Jorge escrevia, simultaneamente, os seus livros. Num espaço vazio de sua atividade profissional, quando comia ou antes de dormir, o fabuloso Jorge dava andamento aos seus romances, concluía um poema, recriava a vida. [...] Tenho para mim 
que Jorge intencional-

mente entregou-se aos dois trabalhos para testar a sua capacidade criativa. O Anjo e Calunga eram fagulhas do mesmo incêndio". (Vida e obra de Jorge de Lima. Rio de Janeiro: Correio da Manhã, I969, p. I27). abandono da região pelo homem instruído, que, ao tentar voltar para a civilização, acaba morrendo ou mutilando-se. Contudo, de todos esses aspectos, os que mais se destacam são as imagens arquetípicas ligadas ao Gênesis e à queda e a preocupação social com a população nordestina.

Em A mulher obscura, o drama existencial vivido pelo protagonista, o escritor Fernando, é uma espécie de retomada de algumas das questões apresentadas por Herói, em $O$ Anjo, como as reflexões estéticas e a busca pela sua Bem-Amada.

E Guerra dentro do beco, embora se apresente mais carregada das nuanças sociais, representadas pela Segunda Guerra, mostra um aprofundamento das idéias sobre arte e religião disseminadas nas obras anteriores.

Considerado o conjunto, destacam-se as imagens arquetípicas relacionadas com o Gênesis e a queda. Além disso, chama a atenção o fato de os protagonistas dessas obras - Herói (pintor), Lula (o nordestino que sai de sua terra natal para as capitais), Fernando (escritor) e Júlio Aguiar (pintor), todos eles divididos entre a cidade do Rio de Janeiro e o Nordeste - apresentarem algumas das múltiplas facetas do próprio Jorge de Lima, intelectual alagoano radicado no Rio de Janeiro, dividido entre a medicina, a literatura, as artes plásticas e a militância religiosa.

Neste estudo, abordaremos apenas um desses aspectos, o religioso, procurando num primeiro momento isolar o fio condutor que liga as obras de ficção do escritor alagoano e, num segundo momento, estabelecer os nexos entre essa ficção e o movimento de renovação católica que marcou parte da vida cultural e intelectual brasileira na década de 30 , especialmente suas relações com o essencialismo de Ismael Nery.

\section{Em busca do fio partido}

Muitos são os episódios e alusões relacionados com o universo religioso nas obras de ficção de Jorge de Lima. São de tipos variados e vão de simples referências a igrejas, padres, pecadores ou citações diretas de figuras expressivas da história do cristianismo, como Teresa D’Ávila e Jacques Maritain, até imagens arquetípicas elaboradas, relacionadas aos episódios bíblicos do Gênesis, da queda edênica e da morte de Cristo.

Em $O$ Anjo, as alusões, diretas ou implícitas, a um universo espiritualizado e transcendente são constantes. Destacam-se alusões de três tipos: as feitas sobre a queda, sobre a Bem-Amada e sobre a personagem Anjo. 
A queda constitui um dos eixos centrais da configuração religiosa da prosa de Jorge de Lima. O tema aparece sob múltiplos aspectos, desde uma queda pessoal do protagonista até a noção de queda coletiva (a queda social do homem), e ainda a sugestão ou a menção direta à queda edênica.

A queda pessoal se dá com a decadência artística e social do protagonista, que passa da condição de pintor, com exposição freqüentada pela crítica e pelo público, à condição de viciado (no álcool e no jogo) e marginalizado socialmente.

Por vezes a queda da personagem é tão carregada de sentimento de culpa que ela transcende o plano pessoal e evoca o pecado original. A queda edênica, então, é sugerida, como neste fragmento:

Herói não tinha vocação para o mundo. Toda a luta o cansava. O homem nasceu para descansar e para contemplar e só por castigo luta e trabalha. Herói tinha reminiscência de remotas faltas em que fora comparsa: era um decaído, sem dúvida. ${ }^{3}$

Em O Anjo, como nas demais obras em prosa de Jorge de Lima, essa identificação do protagonista com a condição adâmica é vista com fatalismo: independentemente de ter ou não consciência disso, de ter ou não feito essa opção, o homem cumpre um destino traçado desde tempos remotos.

Mas não é um destino que leva somente para baixo; a queda é também um salto para o alto, pois, de acordo com a concepção da obra, é padecendo todos os sacrifícios possíveis do caminho que se consegue chegar ao autoconhecimento, à libertação ou à redenção.

Nesse sentido, a trajetória de Herói assemelha-se à de todos os heróis da literatura: o herói clássico, o romanesco e, até certo ponto, o problemático. Assemelha-se também à do herói máximo da cultura cristã, em cuja morte e sofrimento se situa o símbolo maior da remissão dos pecados do homem e, ao mesmo tempo, de sua libertação.

Sem pretensão realista, com gênero literário indefinido, $O$ Anjo é uma narrativa alegórica que visa representar, sob uma perspectiva cristã, a trajetória do homem no planeta, desde a Criação. E, tal como ocorre com toda a história cristã, seu objetivo é transmitir uma mensagem de redenção e esperança.

Ao atirar-se do alto do edifício, no final da obra, Herói repete o destino de Adão, cuja queda se deve à ousadia de querer conhecer o bem e o mal, conhecer o mundo. Como conseqüência de seu gesto, Herói perde a visão e as mãos, espécie de sacrifício e punição ao mesmo tempo.

Privado dos órgãos principais que teriam levado o homem original ao peca-
3 IIma, Jorge de. Calunga e O Anjo. $3^{\underline{a}}$ ed. Rio de Janeiro: Agir, 1959, p. 194-5. 
$4 \mathrm{Na}$ página I8 5 da edição citada na nota anterior, o Anjo pergunta a Herói: - A Bem-Amada é morena ou loura? Ora tu dizes que é morena, ora dizes que ela é loura. E então?". $\mathrm{Na}$ descrição do quadro que representava a Bem-Amada (p. I86), são mencionados apenas dois traços que a caracterizam: "O sexo em triângulo negro. Ombros hieráticos" 5 Calunga e O Anjo, p. 186.

6 Idem. do, Herói, representando todos os homens, retorna finalmente ao estado de treva ou de não-consciência do bem e do mal; reencontra-se com o Adão anterior à queda; reintegra-se ao estado de inocência original. Daí a sensação da personagem de ter finalmente encontrado a Bem-Amada, de ter-se libertado do tempo cronológico.

Como Adão, Herói vive todos os pecados: o exílio, a sedução, o vício, a decadência. Como Cristo, passa pelo sacrifício e, nele, em sua morte simbólica, está a própria ressurreição, o renascer para o tempo mítico.

Se a queda de Adão representa na cultura cristã o destino humano do trabalho e do sofrimento, é provável que, na visão de Jorge de Lima, a queda seja justamente o caminho que leva para o alto, pois, de acordo com o seu ponto de vista, é do sofrimento e da dor que nasce ou renasce a vida.

A Bem-Amada, no âmbito explícito da narrativa, é o objeto de procura do protagonista de $O$ Anjo. Nas duas únicas vezes em que são descritos os quadros de Herói, o tema de um é o Anjo e, do outro, a Bem-Amada.

Em todo lugar, Herói busca esse ideal feminino: no circo, nas ruas, no hospital. De formas físicas indefinidas, ${ }^{4}$ a Bem-Amada é a evocação de uma mulher morta que Herói vira na infância: "A Bem-Amada deveria ter um certo ar de moça morta que ele viu na meninice (A volúpia imortal que vinha de eras remotíssimas...)" 5

Ela não imitava uma mulher comum e real, pois "traduzia uma sensação sexual cerebral" No quadro que a representava, "um grave fundo místico confundia cores e linhas, se confundindo, nas molduras" ${ }^{\circ}$

Lembrança da imagem da mulher morta, fruto do inconsciente, espécie de síntese formada por todas as mulheres ("A volúpia imortal que vinha de eras remotíssimas"), a Bem-Amada é um ser incorpóreo e sem vida e, ao mesmo tempo, cheia de sensualidade e misticismo.

Por um lado, a Bem-Amada é o arquétipo da mulher em si, a Eva, com suas características de sedução e pecado. Por outro, é a idéia da mulher amada, o ideal de um ser inalcançável, incorpóreo, irreal; uma espécie de síntese de todas as amadas da literatura - Beatriz, Laura, Nise, Marília - com seu traço nitidamente idealizante e platônico.

Mais do que uma mulher, Herói ama esse ideal de mulher; mais do que a mulher, Herói ama o amor por essa mulher irreal. Herói precisa amá-la, pois só assim, com uma Bem-Amada/Eva, se cumpre seu destino de homem e de Adão.

O Anjo, personagem, é um ser antropomorfo, meio homem, meio ave, que 
assume o compromisso de proteger Herói. Personagens díspares, na origem e na forma de ser, ambos se atraem e se completam. Aos poucos, seus papéis se invertem e se confundem. Herói cada vez mais se distancia da vida real e mergulha num mundo de abstrações, por meio da bebida e do jogo. É nesses momentos que mais se identifica com o Anjo:

Quando Herói se embriagava virava onça para todo mundo. Para o Anjo não [...] Ficava fora do tempo e do espaço e encontrava verdadeiramente o Anjo.?

Ou, quando Herói jogava, "virava puro espírito não ligando mulher, nem percebendo tempo e espaço" ${ }^{8}$

O Anjo, por outro lado, assume compromissos em lugar de Herói, cuida de assuntos práticos e até da parte financeira do amigo. Protege-o, como é de se esperar de um anjo com o nome "Custódio"

Cada vez mais assume feições humanas, a ponto de se conhecer seu passado, que incluía uma escola, uma professora e até desejos reprimidos por ela.

Herói, embora humano e real, está para o desejo e o inconsciente como o Anjo está para a consciência e para a realidade. Herói quer ser puro id; o Anjo é seu superego.

Dentro da visão de mundo de Jorge de Lima, talvez essa contradição possa ser expressa pelo dualismo entre o bem e o mal, no sentido mais amplo possível dessa antítese. Conforme as palavras do próprio narrador, "Herói, ser duplo, tinha uma banda contra ele. Num hemisfério do homem estava o bem, no outro o mal". 9

Se a queda de Herói é um salto para o alto, a ascendência espiritual do Anjo é diametralmente oposta: é um salto para baixo. A trajetória de Herói, embora cheia de percalços que confirmam sua condição essencialmente humana, tende a elevá-lo para um ideal transcendente e superior. Na mesma medida, o Anjo, embora de origem celestial, tende à humanização, repetindo a trajetória de Cristo.

As relações entre o Anjo e Cristo são explícitas. Neste episódio, por exemplo, depois de adormecer e sonhar com a escolinha da professora Mônica, o Anjo acorda triste:

O Anjo ficou tristíssimo porque percebia que o seu sono era corporal como o dos demais e só seu espírito pairava sonâmbulo pelos acidentes da terra. Mas quando, às vezes, acontecia voltar às origens, percebia a destinada ligação com o Herói já no
7 Idem, p. I99.

8 Idem, p. 20 I.

9 Idem, p. 246. 
IO Idem, p. 2 I5.

II Na p. 208 da edição citada, Herói grita: '- A solidão do Anjo deve ser enorme mesmo em Paris ou em Hollywood! O Anjo se humanizou para me salvar! Pobre Anjo!" traçado de Deus, e o minuto da vida era uma coroa de espinhos sobre sua cabeçorra de ave que sangrava sob todas as dores. ${ }^{\circ}$

Como Cristo, o Anjo é o divino humanizado, pateticamente deslocado de seu meio para o materialismo e o cientificismo das metrópoles. ${ }^{11}$ Glosando a narrativa cristã, é preciso que o divino seja homem para compreender a condição e a dor humana, pois somente essa espécie de rebaixamento é capaz de levar o homem ao seu estado de ascensão original.

Herói e o Anjo não são personagens comuns a romances realistas. A começar pelos seus próprios nomes - vale lembrar também os das demais: BemAmada, Padre-Mestre, Mãe, Pai, Salomé - a obra apresenta personagens e tipos alegóricos cujo significado se situa no lastro da tradição religiosa e cultural do Ocidente.

Excetuando-se Herói e o Anjo, que recebem algum tratamento psicológico, as demais personagens são tipos alegorizantes que apenas cumprem um papel determinado pela tradição cultural. Pai e Mãe representam as origens, um ponto de referência, um porto seguro. Padre-Mestre é a voz da verdade, do aconselhamento; é o caminho distante e difícil da Igreja e do bem.

Quanto às mulheres, da mesma forma que Herói e o Anjo, são como duas faces da mesma moeda. A Bem-Amada e Salomé representam o dualismo da figura feminina no contexto da cultura judaico-cristã: de um lado, ela é um ideal transcendente, a própria idéia do amor; de outro, é pura carne, sensualidade, vulgaridade e degradação. Pode-se dizer que também aqui o ideal amoroso está sujeito a duas forças iguais e de sentidos contrários, uma que tende à elevação e outra ao rebaixamento.

Herói e Anjo, Bem-Amada e Salomé, entre um salto para cima e outro para baixo, representam a condição humana, o homem universal, acorrentado ao tempo, dividido entre o bem e o mal.

Entre as obras de ficção de Jorge de Lima, Calunga é a que mais se aproxima do romance regionalista do segundo tempo modernista. Acentua-se nesse romance o caráter de denúncia social, ao mesmo tempo que diminuem as referências religiosas explícitas. Apesar disso, o universo natural da obra - como também se dá em $O$ Anjo, no episódio em que Herói e o Anjo vão ao Nordeste, atendendo ao chamado da mãe de Herói - pelo seu aspecto informe e primitivo, associa-se diretamente à criação do mundo.

Lula, o protagonista, desejando dominar e transformar a natureza da ilha de Santa Luzia, frustra-se como um Adão decaído: "O homem decaído sentia- 
se descer abaixo do solo lamoso da ilha. O mundo esmagava-o. [...] Ele não era 12 Idem, p.206. nada, ele não existia." ${ }^{\prime 2}$

As imagens bíblicas e arquetípicas existentes em Calunga e em $O$ Anjo podem ser mais facilmente compreendidas com o auxílio da Bíblia. Convém observar também que o período de gestação dessas duas obras - provavelmente entre I933 e I935 - é rico espiritualmente na vida do autor, pois coincide com sua reconversão ao catolicismo e com a escritura de Tempo e eternidade, em parceria com Murilo Mendes.

Um exame do Gênesis revela que, no episódio da Criação, Deus teria feito o mundo a partir de relações de oposição. Primeiramente criou os céus e a terra; depois separou a luz das trevas, criando assim o dia e a noite. Em seguida, separou das águas (mares) a porção seca (terra), criou a lua e o sol, os animais (machos e fêmeas) e finalmente o homem, Adão, e, a partir dele, a mulher, Eva.

Ainda nos episódios da formação do jardim do Éden e da tentação, também se verificam outras polaridades: as árvores cujos frutos podiam ser comidos e aquela cujo fruto era proibido; a existência do bem e do mal; e, após a queda, a vida na Terra e o paraíso perdido.

Pelas descrições de Calunga, toda a ilha de Santa Luzia era um grande atoleiro. Lula tinha enorme necessidade de pisar solo firme, de sentir-se seguro, de aprumar-se, de fazer um mundo novo e limpo emergir da lama, mas "[...] os pés tropeçavam no chão incerto da fraqueza humana"

Relacionando-se o espaço físico de Calunga aos elementos bipolares da Criação mencionados, nota-se que a ilha não se situa exatamente nem na parte seca nem nas águas da criação do mundo. É um espaço intermediário, informe, ambíguo, que se assemelha à condição do homem pós-queda, isto é, o homem dividido entre o bem e o mal, entre a Terra e o paraíso, entre Deus e o diabo.

Lula, com seus ideais iluministas, quis civilizar e modernizar a ilha de Santa Luzia, mas sucumbiu diante das forças da natureza, da ignorância, do fanatismo religioso e das doenças.

Não se trata, nesta obra, do enfoque determinista que caracterizou alguns dos romances de 30 ao retratarem a impotência do homem diante das forças naturais e sociais. Em Calunga, Lula transcende a figura do iluminista regionalizado para ganhar uma significação universal. Igualado em tudo ao mundo que negava e combatia, representa a própria condição humana: também ele, como os demais habitantes ignorantes da ilha, contrai a maleita; também ele come o barro, ama a prostituta e crê no falso santo; também ele mata o inimi- 
13 No Gênesis, lê-se a respeito da aventura humana, em sua sede de conhecer: "Então disse o Senhor Deus: Eis que o homem é como um de nós, sabendo o bem e o mal; ora, pois, para que não estenda a sua mão, e tome também da árvore da vida, e coma e viva eternamente; O Senhor Deus, pois, o lançou fora do jardim do Éden, para lavrar a terra de que fora tomado" go, pensando que mata a si mesmo. Lula comete todos os pecados, como um Adão decaído, que ousou saber tudo e conhecer o bem e o mal.."

Assim como Lula, em $O$ Anjo Herói também é uma personagem dividida bipolarmente entre o meio rural e o urbano; entre o ideal platônico da BemAmada e os amores vulgares, representados pela cabocla nordestina e depois por Salomé, mulher maligna e satânica; entre a vida de intelectual burguês e o sentimento de solidariedade para com os oprimidos; entre o bem e o mal, componentes de sua identidade de anjo e homem.

Como o homem original, Lula e Herói também ousaram conhecer, também desafiaram as convenções de seu meio e se dirigiram à capital, em busca do saber. O conhecimento adquirido na metrópole, entretanto, resulta inútil: não beneficia a ninguém, nem mesmo a eles.

Filhos de um meio natural indefinido e informe - em que o homem se confunde com o barro, comendo terra e adentrando-se sensualmente na lama Lula e Herói, como Adão decaído, são também criaturas indefinidas e imperfeitas.

Todos os crimes cometidos por Adão e por seus descendentes, eles também cometeram; todos os dualismos nos quais estão envolvidos são também os que envolveram o homem original e a criação do mundo. Lula e Herói representam, enfim, a síntese da condição humana em seu trágico destino de ter de optar entre saber e não saber, entre o bem e o mal.

Em A mulher obscura, abundam as referências ao universo mítico-religioso. E são feitas em meio a uma série de sugestões psicanalíticas, recriando as situações já observadas em $O$ Anjo: inconsciente, queda individual, conflito entre amor físico e amor espiritual, sentimento de culpa, aspiração ao transcendente.

Quanto às sugestões psicanalíticas, é evidente a intenção do autor de empregar na obra as novidades introduzidas por Freud e pelos surrealistas quanto ao inconsciente. Contudo, não se trata de procedimento surrealista. Em A mulher obscura, as zonas inconscientes da mente humana vêm carregadas de sugestões bíblicas e estão relacionadas com o tempo mítico da origem do mundo:

Mergulhado de novo no sono, tinha incorporado sem esforço uma idade de minha vida primitiva, perdida entre limos incertos do começo das coisas.

De repente os sete dias da criação nasciam do barro de membros insensíveis.

E se dá no curto espaço do meu sono uma como recapitulação de uma história longa, vivida pelo meu inconsciente, em que culpa, desobediências e novas ameaças se sucedem, transportadas às realidades de hoje, mas em que me reconheço como comparsa de um mistério de que perdi a memória, não sei quando. 
[...] E, assim como Eva nasceu de uma costela de Adão, uma mulher podia nascer ou nascia verdadeiramente durante o sono, de uma falsa posição de sua coxa. E o ser criado e autônomo passaria a cometer com o seu próprio criador os incestos primitivos. ${ }^{14}$

Como se nota, para o narrador-personagem o sono ou o mergulho do eu nas zonas mais profundas do ser guardam ressonâncias de um tempo e de uma história míticos que diferem de sua história pessoal, porém de alguma forma a ela estão ligados.

Momentos antes, o narrador dizia viver uma confusão de tempo e de espaço "que devia ser a confusão do Limbo" Em seguida, refere-se a uma "vida primitiva, perdida entre limos incertos do começo das coisas"

É como se a cada noite, em cada sono, o homem entrasse em comunhão com o tempo mítico genesíaco, revivendo a história de sua condição; como se a perda da consciência lhe abrisse as portas de um inconsciente coletivo que apontasse sempre para uma mesma direção: a da criação, do pecado, da queda e da busca do paraíso perdido - a direção que também é a do protagonista de $O$ Anjo.

Aliás, vários componentes daquela obra se repetem aqui, como é o caso do ideal feminino transcendente, a Bem-Amada. Até mesmo a figura de PadreMestre Anselmo, que em $O$ Anjo dá conselhos religiosos a Herói, agora reaparece com o nome Josué; e é ele quem cria a frágil e doente Constança, o ideal amoroso de Fernando, a Bem-Amada deste.

Fernando nutre pela moça um amor fraternal, só raramente quebrado por um desejo reprimido. Com a morte dela, ele se sente culpado. ${ }^{\text {is }}$

Padre-Mestre vê, na idealização feminina de Fernando, uma relação direta com a morte da mãe do protagonista. $O$ amor sublimado que sentem Fernando, de $A$ mulher obscura, e Herói, de $O$ Anjo, assume feições edipianas. Por um lado, o amor pela Bem-Amada deve ser privado de qualquer interesse sexual; por outro, toda vez que se entregam à prática sexual, enchem-se de culpa e insatisfação, pelo fato de as mulheres não corresponderem ao seu ideal sublimado; por outro lado ainda, o próprio texto de $A$ mulher obscura associa a lembrança da morte da mãe de Fernando à morte de Constança.

Além disso, em $O$ Anjo, o destino de Herói — a perda da visão e a amputação das mãos - é um claro exemplo de autopunição ou autocastração.

Apesar dessas considerações psicanalíticas latentes nas duas obras, compreendemos que esse veio, ao lado de tantos outros, se insere no projeto estético do autor, concebido em bases cristãs.
I4 LIMA, Jorge de. $A$ mulher obscura. Rio de Janeiro: Agir, I959, p. $27 \cdot 8$. $15 \mathrm{Na}$ página $180 \mathrm{da}$ edição citada na nota anterior, lê-se: "Repentinamente, tomou-me a desconfiança de que o meu egoísmo, quase sexual, pelo menos erótico, tinha sido a causa da morte de Constança" 
I6 A mulher obscura,

p. 84-5.

I7 Observe-se este tre-

cho da obra: "A minha

pessoa, enfim, desejava,

conservando a sua

egoística singularidade, pertencer ou diluir-se no universal, e o universal repelia, com todos os direitos que lhe assistiam, esse ser que se reconhecia superior ou inferior a ele, ou diferente da maioria das pessoas que o compunham". A mulher obscura, p. 236.

I8 Idem, p. 236.

I9 Veja-se este exemplo: "no meio das exaustivas preocupações do estudo, ou de outra ordem de trabalho mental, ou caminhando sem objetivo pelas ruas, parece-me que entrevejo, com a mesma obsessão de outrora, uma face perdida, que tenho de reencontrar entre os habitantes da terra. (A mulher obscura, p. 235).

20 Idem, p. 235.
Fernando, tal qual Lula ou Herói, tem sobre si o peso da humanidade. Não é um só homem:

Muitas vezes penso na multidão que existe morando no meu ser, movendo-se constantemente como um mar. Os seus mais modestos passos são pulos de morte. [...] Quantos Cains sedimentaram dentro de mim? Quantos Abéis se sacrificaram para que a criação continuasse? [...] Quantos matei? Quantos traí? Quantos ungi com a minha amizade? Sinto que ando com os pés de criaturas que caminharam até a coagulação do momento que eu sou. Há inimizades entre as minhas mãos. Há indecisões na minha fronte.

E o arraial vive tumultuando em mim, indeciso, inquieto, à procura de quê? De que bem-amada inacessível, de que fome de perfeição tudo isso se move ${ }^{\text {r6 }}$

"Coagulação" de seus ancestrais Fernando não é um. Representa a síntese de todos os homens, de todas as épocas da história, de todos os crimes e paixões humanas, é uma espécie de Adão contemporâneo, que ainda paga o preço do primeiro pecado. Assim, segue a sina da personagem bíblica: fuga, isolamento, incompreensão.

Os sentimentos de Fernando são contraditórios: sente "uma espécie de mal estar perante os outros" ao mesmo tempo que o desejo de viver entre seus semelhantes, de unir-se a eles em comunhão. Isolado, não satisfaz seu anseio de universalidade. ${ }^{17}$

O drama pessoal vivido pelo protagonista ganha universalidade, à medida que ele tem consciência de que sua trajetória particular é a representação da história do homem e de seus desenganos. Dividido, fragmentado, sua identidade dilacera-se:

Olhando-me ao espelho, via que a minha face era diferente da face humana: uma certa noite ninguém me reconheceu, notei que todos os meus conhecidos me apontavam ou riam quando eu passava. ${ }^{18}$

É no contexto dessa busca incessante de si mesmo e de um sentido existencial que se coloca a questão da "face perdida" Embora a obra narre a busca de um ideal feminino, essa face é associada à face de Cristo: "não seria esta face uma reminiscência da face do Cristo, de Quem o homem é semelhança, como Ele próprio O é de Deus?" ${ }^{\circ}$

Nas páginas finais da obra, o narrador foge de Madalena e chega a certo vi- 
larejo. Cansado, com muito sono, cambaleando pelas ruas, hospeda-se numa pensão barata, no quarto de uma prostituta. Coincidentemente, ela também se chama Madalena e está fora, tentando conseguir o dinheiro do quarto, que há muito não paga.

Fernando dorme durante horas e acorda assustado com o escândalo que se armava na rua e na pensão. A prostituta, que volta sem o dinheiro, está sendo despejada pela dona da pensão. Entra no quarto de Fernando apenas para pegar seus pertences e partir.

Fernando tenta sair do local e livrar-se daquela situação constrangedora, mas a prostituta cai a seus pés e agarra-lhe as pernas, diante dos protestos da multidão, que entra na pensão e se aglomera à porta para ver a cena, gritando: “Não pode!” Glosando os gestos de Jesus, o protagonista acolhe a prostituta e contraria a multidão, cuja ira é abrandada com a presença da "senhora de ÁguaFria, com a mesma cara de loucura, a mesma touca de folhos, o mesmo papo de rendas, como de ave" que diz: “—É o filho de Deus! Não estão vendo que é o filho de Deus!"21

São claras as relações entre esse episódio de A mulher obscura e o episódio bíblico de Madalena, a prostituta. Assim como Cristo, também Fernando, por caridade, acolhe a prostituta e se põe em risco diante do desejo do povo.

Nem mesmo Fernando esperava agir daquela forma para com a prostituta. Descobre em si, ou melhor, assume, naquele momento, o outro lado do seu ser: o lado solidário, humano, altruísta, abafado pelo eu individualista.

Madalena, a prostituta, a mulher cheia de culpas e de erros, mais uma vez cumpre seu papel. É o espelho no qual os homens vêem seus próprios enganos. Ninguém atira a primeira pedra.

Fernando descobre, em seu próprio rosto barbudo e sereno, a face perdida tão procurada. Não é a de nenhuma mulher, é a face de Cristo. Por meio do cristianismo, o protagonista consegue seu intento de estar entre todos, de dividir-se igualmente entre os homens. Aos olhos de Fernando, o cristianismo é "a comunhão mais ampla e verdadeira, junto da qual os pequenos comunismos, mutilados e inventados pelos homens, são plágios vergonhosos". ${ }^{22}$

Da mesma forma que Calunga está umbilicalmente ligada a um episódio de O Anjo, A mulher obscura pode ser vista como o aprofundamento de duas idéias básicas daquela obra: o ideal feminino transcendente e o conceito da eterna busca.

A mulher obscura, assim como as obras que a precederam, também glosa a narrativa bíblica, principalmente em seus episódios da queda e do sacrifício de
2I Idem, p.265. 22 Idem, p.76. 
23 Guerra dentro do be.

co. Rio de Janeiro: Agir, I950, p. I20-I.

Cristo. Já a cena final da prostituta, mais do que glosa, é uma recriação e uma transposição direta do episódio bíblico, como se a história humana, em sua essência, se repetisse infinitamente, com os mesmos impasses e contradições, independentemente de seu contexto histórico.

Jorge de Lima, ao glosar com sua ficção a narrativa sagrada, aspira à abstração do tempo e do espaço. O homem é um só e um só é o seu destino. Contar a sua história é anunciar o seu futuro.

Em Guerra dentro do beco, o beco a que se refere o título da obra é, por um lado, o beco do próprio interior das personagens, um beco sem saídas, de comunicação inviável, de solidão; por outro, é o beco social de suas principais personagens, artistas, intelectuais, gente de classe média que vive o beco sem saída da Segunda Guerra Mundial; por outro, ainda, pode ser o beco em que se encontra o homem em sua trajetória pela vida desde a queda.

Apesar das referências externas, sociais, a obra é predominantemente metafísica e psicológica, permitindo, mais uma vez, amplas reflexões sobre a condição humana.

Nesse romance, as alusões bíblicas são em menor número do que as de $A$ mulher obscura; porém, as que existem são bastante explícitas, posicionando nitidamente as personagens e, até certo ponto, o próprio autor diante das idéias religiosas amplamente divulgadas na época, particularmente as do pensador católico Jacques Maritain.

Uma das personagens principais da obra - embora assuma no conjunto das ações um papel secundário - é Cristiano, um sociólogo, ensaísta, humanista e poeta. Marcam-no a clareza e profundidade de idéias e a capacidade de compreender de modo racional a complexidade do mundo. Estabelece com os que o cercam uma relação de superioridade de direito, em virtude de seus conhecimentos.

Várias idéias religiosas da obra vêm à luz por meio de Cristiano. Na carta que ele recebe de Carolina, por exemplo, ela comenta um livro do amigo:

\footnotetext{
A hora é de pregação e renovação. E a sua poesia traz um Cristo vivo, um Cristo para ficar conosco, um Cristo muito diferente daquele que conhecíamos, sempre distante, enfeitado, esquecido. [...] Deixei passar 6 ou 8 dias. Reli. Então eu pude compreender. E reconheci o herói, o mesmo que nos romances e nos poemas interroga e sofre, e sangra os pés e as mãos, e queima os olhos numa procura angustiosa e incessante. E como é difícil chegar à Face perdida com o lado enlameado de nossas roupas ${ }^{23}$
}

Não estariam aí sintetizadas a cegueira e a mutilação de Herói, a lama da con- 
dição humana representada por Lula, a "procura angustiosa e incessante" de Herói e Fernando, a busca da "face perdida" de A mulher obscura?

São constantes na obra referências às idéias e aos autores que circulavam entre o grupo de intelectuais católicos do Rio de Janeiro durante o Estado Novo, no contexto da Segunda Guerra: Marx, São Tomás de Aquino, Jacques Maritain, Santa Teresa d'Ávila.

Contudo, o episódio religioso mais significativo da obra ocorre em seu desfecho. Bruna, a esposa de Júlio Aguiar, o protagonista, encontra-se hospitalizada por causa de um aborto voluntário. No hospital, ela tem contato com um menino de quem começa a gostar e a quem passa a proteger. Contudo, o pai do menino mata o filho e se mata em seguida. Bruna piora da saúde e vem a morrer. Júlio Aguiar também adoece e fica no mesmo quarto em que Bruna estivera internada. Certo dia, Júlio sai ao jardim do hospital e impressiona-se com a imagem fugidia de uma mulher que ali caminha, vestida de preto, de andar gracioso e esquivo, de expressão moral rara, olhos negros.

No dia seguinte, reencontra-a. É a mãe do menino assassinado. Caminham juntos pelo jardim, de tal forma posicionados diante do sol, que suas sombras se fundem numa só.

Eram, por assim dizer, dois seres sós e iniciais, que ninguém estava vigiando, a não ser eles mesmos, com a nudez dos seus mesmos olhos, tal como os dois primeiros habitantes do jardim terreal. Na verdade, o mundo e tudo o mais havia desaparecido para eles, e naquele instante, só existia, de visível e real, em torno das duas testemunhas o imenso parque deserto. ${ }^{24}$

Em outro trecho, os dois seres são deste modo descritos: "E assim unidos, asa com asa, pensamento com pensamento, pareciam ir levitados, deslizando, incorpóreos, à superfície de um deserto"

As imagens bíblicas são marcantes: "seres sós e iniciais" "a nudez dos seus mesmos olhos" "os dois primeiros habitantes do jardim terreal" Mas não há nenhuma marca de erotismo entre o casal. Incorpóreos, suas sombras formam o impalpável. "E este ser, andando de rojo sobre ela, escapava, no entanto, a seu contato, com a leveza de um espírito do Senhor, avançando, sem recuos, contra os obstáculos do caminho." 25

Aproximando-se o casal de uma pitombeira, "uma rarefação da folhagem desenhou um coração luminoso no centro compacto da figura" Por fim, na cena final, o casal transpõe o portão do hospital:
24 Idem, p. 282. 25 Idem, p. 283. 

manente da grande cidade confundia vertiginosamente homens e veículos apressados. Olharam em torno: a sombra tinha desaparecido.

E eles haviam sido envoltos no pereno turbilhão. ${ }^{26}$

Por um momento apenas, no jardim do hospital, Júlio Aguiar e a mulher misteriosa (por que não chamá-la de "mulher obscura"?) tornam-se um único ser. Um ser "duplo, bissexuado, que era a superposição de suas sombras" Ambos haviam perdido seus entes queridos por causa da loucura do mundo e da loucura do amor: ela perdera o filho, assassinado pelo próprio marido, que via no menino seu inimigo; ele perdera a esposa, cuja morte se explicava pelo aborto do filho, provocado por ela mesma.

Ambos carregam nos ombros toda a culpa da humanidade; ambos alegoricamente representam todas as paixões e ódios humanos, todos os crimes e criminosos que existiram na história do mundo e existem em cada um de nós. São, a um só tempo, o homem e a mulher primeiros, bem como o homem e a mulher contemporâneos. Eles representam, enfim, a humanidade em sua trajetória de conquistas e descobertas, sem rumo definido, sem objetivos claros, sem saber que o sentido de todo mistério, de acordo com a visão do autor, encontra-se no próprio mistério, que o homem repetidamente nega.

A mulher que forma uma unidade com Júlio Aguiar, mesmo que por um segundo apenas, corresponde ao ideal da Bem-Amada de Herói, em O Anjo, e ao da mulher obscura de Fernando, em $A$ mulher obscura. E o coração de luz que os liga na sombra una representa o amor cristão, o amor de Deus, a caridade.

Como se vê, o ideal feminino e transcendente dos protagonistas dessas obras implica a própria negação do mundo concreto em que estão inseridos e a aspiração ao mundo mítico e transcendente do Gênesis. Aspirar por uma BemAmada é o mesmo que aspirar a ser homem inaugural.

Jorge de Lima, com suas quatro obras de ficção, é o autor de uma única história: a história do homem, da queda aos dias de hoje.

\section{A queda: a linha e a costura}

Chama a atenção, na leitura da ficção de Jorge de Lima, a insistência com que o tema da queda é tratado. Mais do que mera recorrência temática, ele cumpre 
o papel de verdadeiro elo entre as obras e é o elemento que mais diretamente 27 Idem, p. 283. se ressalta na busca de uma fisionomia do conjunto delas.

O tema aparece sob múltiplas formas, individuais ou coletivas. Às vezes, no plano individual, é enfocado em uma perspectiva moral, como, por exemplo, a bebida e o jogo para Herói; ou em uma perspectiva psicológica: os desejos edipianos de Herói e de Fernando, os sentimentos de culpa de Herói, de Fernando e de Bruna, os impulsos de morte (assassínio ou suicídio) de Herói, de Lula, de Bruna e do pai do menino internado.

No plano social, a queda se dá na degradação das relações humanas e nas condições de vida da população: a extração do sururu, a malária, a miséria, o fanatismo religioso, a violência, o autoritarismo, como exemplifica Calunga e parte de O Anjo.

Além desses tipos de queda, é também recorrente a referência à queda edênica. As imagens arquetípicas - algumas mais, outras menos explícitas - do jardim edênico, do tempo primitivo, do homem primeiro, conferem às obras uma dimensão universal que engloba e transcende os demais tipos de queda.

Essa dimensão universalizante é devidamente embasada pelas personagens, que sempre tendem à alegorização. São personagens paradigmáticas, que se retomam umas às outras (Lula e Herói, Fernando e Herói, Constança e a Bem-Amada de $O$ Anjo, Cristiano e Hilda), e todas retomam as personagens da história original e seu drama universal: Adão e Eva e a expulsão do paraíso.

Herói, dividido entre o bem (o Anjo) e o mal (a outra parte dele mesmo, ou Salomé), representa a eterna escolha que o homem tem de fazer diante dos outros homens e diante de Deus. Lula, a mais realista das personagens, é também a alegoria do trabalho, do sofrimento e da impotência humana.

Na cena final de A mulher obscura, Fernando e a prostituta revivem a cena bíblica da defesa que Cristo faz da prostituta. Fernando e Cristo são igualados no plano do sofrimento e da incompreensão e ambos alegorizam os padecimentos humanos por causa do pecado original.

Em Guerra dentro do beco, obra que fecha o ciclo da ficção de Jorge de Lima, a cena final explicitamente confere às personagens um caráter alegórico e universalizante. São Adão e Eva modernos que, apenas por um momento, antes de se entregarem ao "turbilhão" que há além dos muros do hospital, revivem a unidade perdida no paraíso. "Eram sombras da vida, poderiam se falar sem os impasses que a queda urdia entre os demais seres humanos." ${ }^{27}$

Nas obras de ficção de Jorge de Lima, evidencia-se, assim, a preocupação de narrar com diferentes enredos uma mesma fábula, a fábula original, fonte 
28 Aguilar: Rio de

Janeiro, 1958 .

29 Idem, 77.

30 Idem, p. 93.

3I Idem, p. 95 . e modelo de todas as outras narrativas. Destituídas de rigorosas noções de tempo e espaço, as personagens dessas obras são sínteses ou "coágulos" de inúmeras gerações passadas, espécies de Adões e Evas deslocados, vivendo as tentações e quedas próprias do mundo moderno.

A queda é o elo entre essas obras; é o material, é a linha usada nas diferentes costuras, nos diferentes enredos dados à narrativa original.

Em entrevistas reunidas no "Auto-retrato intelectual" da Obra completa ${ }^{28}$, Jorge de Lima mais de uma vez se refere ao tema da queda.

$\mathrm{Na}$ entrevista reproduzida no ensaio publicado no Diário Carioca, em I948, ao tratar da poesia, da arte e do artista contemporâneo, o autor afirma: "Confuso e nômade, o homem moderno, como o homem da Queda, percorre simultaneamente vários caminhos com o resto da ubiqüidade que lhe sobrou." ${ }^{29}$

Em entrevista concedida à Tribuna da Imprensa em 7.6.1952, perguntado sobre a idéia central de Invenção de Orfeu, responde:

A idéia central deste poema é a epopéia do poeta olhando como herói diante das vicissitudes do mundo através do tempo e do espaço.

O que atravessa o poema de ponta a ponta é o drama da Queda. Sem a Queda não haveria história, não haveria epopéia. O poema é um momento da eternidade perdida que o poeta procura conquistar. E todo esse despojamento do espaço, tempo e corpo tende para a concepção do puro espírito capaz de sentir a tragédia da Queda e compreender a tragédia do mundo. O poeta é o seu herói..$^{\circ}$

Em outra entrevista, em resposta à pergunta sobre os objetivos da obra Invenção de Orfeu, esclarece:

O herói desta pretendida epopéia é, em verdade, o poeta em frente ao drama apocalíptico que vive o mundo de hoje, com os seus terrores, as suas ameaças de destruição, os seus vícios, as suas desgraças..$^{31}$

E mais adiante, na mesma entrevista, afirma:

O grande drama do cristianismo é o drama da Queda, pois não é? É esse grande drama que atravessa o poema de ponta a ponta.

Nós sabemos, meu amigo, que mesmo o fenômeno histórico, todo ele, não é mais do que o détour do pecado. Nós perdemos com a Queda os atributos angélicos da ubiqüidade, da imortalidade e à custa de suor e de lágrimas, sofrendo e chorando, 
procuramos reconquistar, em vão, esses atributos perdidos, com a televisão, o rádio; procuramos reconquistar as nossas asas que perdemos, a nossa visão ubíqua e a imortalidade pelos poemas sem tempo e sem espaço que possamos construir.

Como se nota, eram importantes para o autor idéias como ubiqüidade, abstração do tempo e do espaço, sofrimento humano e, especialmente, a da queda, que preside a todas as outras.

Pode-se até supor, com base nesses relatos pessoais de Jorge de Lima, que não apenas Invenção de Orfeu ou suas obras em prosa têm em vista narrar o drama humano pós-queda, mas toda a sua obra literária, ou, pelo menos, a parte mais significativa dela, posterior à conversão do escritor ao catolicismo.

É possível que, na concepção do autor, a implacável necessidade humana de conhecimento - origem da queda, segundo o mito cristão $0^{32}$ - repetiu-se seguidamente ao longo da história e ainda se repete nos dias atuais, sob a forma de incessantes buscas no campo da ciência e da tecnologia.

Talvez, para Jorge de Lima, o fazer literário fosse o resultado, antes de tudo, de um compromisso com a causa humana. E, na sua concepção, a resolução das condições negativas em que se tem dado a existência do homem moderno devesse realizar-se, obrigatoriamente, pelo reencontro do homem atual com o homem inaugural; pela união do tempo presente com o tempo mítico. Daí o seu propósito de resgatar com a obra literária um momento, que fosse, da eternidade perdida.

Jorge de Lima, ao narrar com diferentes enredos a mesma fábula - a fábula da Criação e da queda, procura reatar o fio que liga o homem atual às suas origens e, assim, talvez, dar início a uma nova narração, a narração da história de um homem novo, feito com "barro diferente" conforme a expectativa do protagonista de Calunga.

\section{Jorge de Lima e o essencialismo}

Nas décadas de 30 e 40 do século $\mathrm{xx}$, Jorge de Lima seguramente teve contato com o movimento de renovação católica introduzido na Europa por Jacques Maritain e Étienne Gilson. Essas idéias tiveram ampla repercussão na América Latina e no Brasil, dando origem, no Rio de Janeiro, a um expressivo grupo católico, que contou com Jackson de Figueiredo como uma de suas principais expressões.
32 De acordo com o Gênesis, o anseio pelo saber, por ter elevado o homem à condição de igualdade com o divino, levou-o à perda da vida edênica. 
33 MENDES, Murilo. Recordação de Ismael Nery (III). O Estado de São Paulo, São Paulo, I6.7.1948.
Jorge de Lima chegou, inclusive, a traduzir várias obras de escritores católicos, principalmente de George Bernanos, de quem foi amigo e correspondente durante o período em que este esteve como refugiado da Segunda Guerra na pequena cidade mineira de Barbacena.

Evidentemente, existem muitos pontos de contato entre as idéias religiosas manifestas na ficção de Jorge de Lima e as do grupo de pensadores e escritores católicos europeus. Contudo, para os limites deste estudo, interessa mais compreender eventuais relações entre a ficção do escritor brasileiro e o pensamento essencialista.

O essencialismo foi uma espécie de teoria filosófico-religiosa criada pelo poeta, filósofo e pintor (esta era a ordem de sua preferência) Ismael Nery. Espécie de filósofo sem livros (quase não tinha livros em sua casa), Nery desenvolveu um conjunto de idéias filosóficas em discussões promovidas com os amigos, na maior parte das vezes em sua própria casa. Nunca se dispôs a escrever suas teses e, por isso, poucos textos restaram daquelas reuniões noturnas ocorridas no Rio de Janeiro. Ao todo, ficaram alguns poemas do próprio Nery publicados na revista A Ordem, em fevereiro de 1935, que contêm idéias essencialistas; os comentários de Murilo Mendes sobre esses poemas, publicados na revista $A$ Ordem em duas partes, em março e em abril de I935; e um texto do arquiteto Jorge Burlamaqui, publicado na mesma revista, na edição de abril de I 935.

Sem acrescentar informações novas sobre o essencialismo, mas contextualizando o sistema na vida pessoal e na trajetória intelectual de seu criador, $\mathrm{Mu}$ rilo Mendes, um de seus mais próximos amigos e seguidores, publicou dezessete artigos em O Estado de São Paulo, entre I948 e I949, intitulados "Recordação de Ismael Nery" Ao comentar, num dos artigos da série, o desinteresse de Nery em registrar suas idéias essencialistas, Murilo revela ter sido ele próprio o responsável pelo nome de tal corrente filosófica: “[...] achava que ele deveria partir para os cinco continentes fazendo conferências e divulgando seu sistema filosófico, que eu batizara de essencialismo", 33

Além de Murilo Mendes, freqüentaram as reuniões na casa de Ismael Nery, segundo o próprio Murilo, Jorge Burlamaqui, Antônio da Costa Ribeiro, Evandro Pequeno, José Martinho da Rocha, Antonio Bento, Mário Pedrosa, J. Fernando Carneiro, Aníbal Machado, Dante Milano, Genaro Vidal e outros. Ao que se sabe, Jorge Burlamaqui e Murilo Mendes foram os que mais se aprofundaram nas teorias essencialistas e, não por acaso, foram os únicos que escreveram a respeito do sistema.

O texto que expõe com maior objetividade as idéias do essencialismo é o de 
Jorge Burlamaqui, que procura desenvolver as noções de tempo e espaço a partir de princípios da relatividade, na linha einsteniana, com vários pressupostos da Física, particularmente os da dinâmica, isto é, as relações de um corpo em movimento com o tempo e o espaço.

De acordo com o sistema, cada homem percebe de modo peculiar um dado concreto da realidade. Em princípio, as diferenças são mínimas, porque os homens estão próximos uns dos outros, mas, quando há um distanciamento muito grande entre eles (no tempo ou no espaço), a compreensão do mesmo fato pode ser diametralmente oposta.

Dessa forma, cada ser humano possui uma verdade relativa, que pode, aliás, constituir um erro em relação à verdade absoluta. Para expandir sua sabedoria, ele necessita afastar as causas exteriores do erro, "eliminar o supérfluo do seu essencial, e o supérfluo do essencial dos fatos observados, para atingir mais rapidamente a máxima verdade relativa possivel" ${ }^{34}$.

Jorge Burlamaqui procura ainda mostrar as relações entre tempo e espaço, defendendo o ponto de vista de que "um fato deve ser observado, estaticamente, no espaço justo, e dinamicamente, no tempo justo" Considera, assim, que as observações verificadas no espaço são imperfeitas todas as vezes que houver distâncias excessivas ou falta de distância entre o observador e o objeto. Exemplifica com a posição de uma pessoa diante de um edifício alto: perto demais, não consegue ver o todo; longe demais, considera-o extremamente pequeno. Em ambas as situações, há conhecimento imperfeito da realidade.

Assim, conclui que "a série humana total, descontínua em seus termos, deve procurar se ordenar em diferentes posições, cada uma delas sendo o espaço justo para cada homem" ${ }^{35}$. Essa verdade, segundo ele, também serve para o domínio moral, em virtude de nossos erros de julgamento.

O autor ainda demonstra os efeitos do espaço sobre o ser humano, lembrando que este vive sempre usando os sentidos para se situar em relação ao objeto que deseja possuir. Por isso o espaço é um mal para os sentidos, uma vez que influi nas imperfeições destes.

No plano moral, o uso da abstração do tempo e do espaço é indispensável, pois os erros morais são cometidos com mais facilidade. "Os erros morais são conseqüências de prazeres instintivos, físicos, considerados como bens imperativos. ${ }^{36}$ Os imperativos de conservação dos elementos da vida não são contra a moral, pois esta só repele as necessidades supérfluas da vida sensitiva.

A abstração do tempo, diz Burlamaqui, é necessária no plano intelectual e
34 BURLAMAQUi, Jorge. A Ordem. (Rio de Janeiro), março/ I935, p. 190.

35 Idem, p.I9I. 36 Idem, p.I93. 
37 Idem, p. 194.

38 Idem.

39 mendes, Murilo. Recordação de Ismael Nery (VII). O Estado de São Paulo, São Paulo, 24.8.1948. moral; a abstração do espaço é necessária pelo fato de a vida ser dinâmica, isto é, existir o movimento e a evolução. E dá um exemplo esclarecedor:

Um homem que se estudar em um momento, não se conhecerá. Um homem que estudar uma época de um país, não conhecerá a evolução do progresso neste país. Os momentos e as épocas não são estanques, são ligados aos momentos e às épocas passadas. ${ }^{37}$

Conclui, em seguida, que o essencialista, para estudar a moral de um homem passado, deve levar em conta que numa mesma época há homens de todas as mentalidades:

Um corte na humanidade presente revelará homens de todas as épocas, desde o primitivo até o mais refinado, ao alcance da observação, muito mais eficiente que um produto de cultura..$^{38}$

Explica essa afirmação dizendo que o presente de um homem é resultado do seu próprio passado e do dos seus antepassados. Dessa forma, os julgamentos morais da atualidade são normalmente errados por levarem em conta um determinado momento, e não a vida pregressa das pessoas. Coerente com esse ponto de vista, Burlamaqui chega a atribuir culpa aos antepassados de criminosos, tarados e degenerados e justifica:

O homem em um momento é fatalizado por infinitas causas, em todas as direções. O grão de livre arbítrio que ele possa ainda possuir diante de uma ação só é avaliado na medida justa, com abstração do tempo.

Esse texto - de todos, o que desenvolve com mais clareza as idéias de Nery, mas mesmo assim com passagens obscuras e afirmações nem sempre fundamentadas - ajuda a tornar mais compreensíveis algumas referências de $\mathrm{Mu}$ rilo Mendes ao essencialismo, quase sempre enfatizando a necessidade de abstrair o tempo e o espaço.

Numa dessas referências, Murilo afirma:

Era o essencialismo, baseado na abstração do tempo e do espaço, na seleção e cultivo dos elementos essenciais à existência, na redução do tempo à unidade, na evolução sobre si mesmo para a descoberta do próprio essencial, na representação das noções permanentes que darão à arte a universalidade. ${ }^{39}$ 
Tal qual Burlamaqui, Murilo também se refere à abstração do tempo como forma de o homem evoluir e descobrir o que é essencial. É como se, rigorosamente, não houvesse individualidades. Cada homem é um ser contínuo, é um todo. É seus antepassados e seus sucessores, concomitantemente. Ou, conforme Burlamaqui, "os momentos e as épocas não são estanques, são ligados aos momentos e às épocas passadas."

Murilo Mendes, no mesmo artigo mencionado, comenta:

Segundo o próprio Ismael Nery, o sistema essencialista era em última análise uma reparação ao catolicismo. Sabendo da indisposição, hoje, em geral, contra as idéias católicas, resolveu Ismael apresentá-las sob outras espécies, a fim de evitar o part-pris do interessado. No dia em que o interessado se tomar católico — dizia — o sistema essencialista não lhe adiantará mais nada, pois terá sido conquistado um grau superior e definitivo.

Por meio desse texto, conclui-se que o objetivo central de Nery, com seu essencialismo era o de propagação da fé cristã. Contudo, não se tratava de um ideário falso, um chamariz para atrair o incrédulo. Para ele, as idéias filosóficas do essencialismo já estavam implícitas no próprio catolicismo, que vinha sendo cada vez mais incompreendido.

Impressiona a insistência com que os católicos da época falam da "coragem" de ser religioso naqueles anos. Mas se se toma o depoimento de Jorge de Lima a respeito das críticas que ele e Murilo Mendes sofreram quando publicaram Tempo e eternidade, pode-se ter uma noção mais clara do "patrulhamento ideológico" de então. É o caso, por exemplo, deste comentário de Rubem Braga:

Crer em Deus, ser católico ou protestante, ateu ou panteísta, isso é direito de qualquer um. É uma questão íntima. Mas fazer malandragem intelectual com essas coisas, é triste. Dois homens inteligentes como esses dois, deviam ter vergonha de fazer obra tão tapeadora e vil de reacionarismo. Essas trampolinagens divinas, esse malabarismo pseudo-religioso só têm um resultado: sugestionar os incautos para esquecer o terrível drama diário da exploração do homem pelo homem. [...] Os senhores Jorge e Murilo preferem ficar em suas torres de cimento armado, espiando o céu, longe da luta das multidões que sofrem..$^{40}$

Jorge de Lima não integrou o grupo que se reunia na casa de Ismael Nery para discutir o essencialismo. Apesar disso, tudo leva a crer que tenha tido contato com as idéias do sistema por meio de Murilo Mendes.
40 APUD LIMA, Jorge de, Mística e Poesia. A Ordem. (Rio de Janeiro), setembro/ I935, p. 234. 
4I MENDES, Murilo. Recordação de Ismael Nery (viI). O Estado de São Paulo, São Paulo, 24.8.1948.
Murilo foi um dos amigos fiéis de Ismael até por ocasião de sua morte, ocorrida em I934. Em I935, Jorge de Lima e Murilo Mendes publicam juntos Tempo e Eternidade, que, a começar pelo título, sugere ligação com as idéias essencialistas. Além disso, Murilo ainda devia estar abalado com a morte recente do amigo (principalmente porque se converteu ao catolicismo quando desse fato) e imbuído das idéias que juntos tinham elaborado.

Se o essencialismo somente em parte está presente no ideário de Jorge de Lima, o mesmo se pode dizer com respeito à sua obra de ficção. Nela, o princípio essencialista que se destaca é o da abstração do tempo e do espaço, que se manifesta de duas formas: referências diretas e constantes a essa abstração e à alegorização da condição humana, tomada como síntese de gerações sucessivas.

Das obras de ficção, $O$ Anjo é aquela em que explícita e constantemente se faz menção a esse princípio. Por seis vezes ao longo da obra é mencionado o desejo de Herói de parar ou fugir do tempo, ou de esquecer o tempo e o espaço. Para ele, esse seria o meio de encontrar a si mesmo, encontrar o tempo e a unidade perdidos; de unir o homem decaído e cotidiano com sua aspiração ao bem, representada pelo Anjo.

Esse desejo de Herói coincide com as idéias essencialistas. Em um dos artigos sobre Ismael Nery, por exemplo, Murilo Mendes comenta que o essencialismo é

baseado na abstração do tempo e do espaço, na seleção e cultivo dos elementos essenciais à existência, na redução do tempo à unidade, na evolução sobre si mesmo para descoberta do próprio essencial. ${ }^{41}$ [grifo nosso]

Em $O$ Anjo, a noção de tempo cronológico vivida pelo homem é fruto da queda. O homem mítico do Gênesis não possuía essa noção porque vivia no tempo estático ou no tempo eterno da divindade. Desse modo, fazem parte da condição humana e de seu trágico destino os limites espaço-temporais de que Herói quer se livrar. Desvencilhar-se deles é alcançar um total conhecimento sobre si mesmo e atingir novamente a unidade.

No desfecho da obra, farto de Salomé e do tipo de vida que levava, Herói deseja se matar. "Se o Anjo estivesse aqui pegava nas minhas mãos e não me deixava morrer. As minhas mãos têm maus instintos” pensava ele. Com a mão direita, Herói pega o revólver para se matar, mas a outra não permite. Novamente com a mão direita, "espatifou com um murro o mostrador e os ponteiros do relógio. Era preciso parar o tempo" 
E é na luta entre os dois hemisférios que o formavam - o do bem e o do mal - que Herói é levado pelos pés à janela. Dividido, o corpo de Herói conspirava contra ele mesmo. E vence o mal: a personagem atira-se do décimo terceiro andar.

A tentativa de suicídio merece, aqui, uma reflexão especial. Esse ato nunca foi aceito pela Igreja, mesmo em caso de extrema dor e degradação, motivadas pela doença. De acordo com os princípios católicos, somente Deus pode tirar a vida do homem. Sob esse ponto de vista, a prática do suicídio necessariamente implica a perda da salvação.

A personagem, contudo, desde a infância ${ }^{42}$ via o suicídio como um direito do ser humano. Seu gesto, no desfecho da narrativa, é compatível com o pensamento inicial, mas contraditório com os postulados do catolicismo.

Ainda vivo, mas cego e com as mãos amputadas, Herói tornou-se um aleijão, uma deformidade. Perdeu a noção de tempo cronológico, mas vivia agora outra limitação:

- Meus amigos, nem olhos tenho nem mãos pra acabar direito com a vida. E os meus pés sozinhos já não me podem levar para a morte. Estou preso à força por Jesus.

Passado um minuto, falou mais:

— Eu agia, pretendia fazer arte, me esforçava, eu era tempo. Agora sou múmia, sou espaço. Quero reverter à eternidade morrendo.43

Como se nota por meio desses fragmentos, Herói foge do tempo cronológico, mas não consegue superar os limites do espaço. Espécie de múmia, que sintetiza o passado e o presente, Herói é um corpo vivo, ainda que mutilado.

Pela ótica cristã, por ter desafiado o desejo divino, o da vida humana, Herói é punido. Como Prometeu, Herói está "acorrentado" por Jesus e paga a culpa de seus atos com a trágica condição de estar vivo. Seu desejo de "reverter à eternidade" terá de ser adiado.

Contudo, se por um lado esse "acorrentamento" a Cristo e à vida é uma forma de punição, por outro significa perdão e ressurreição, de acordo com o próprio significado de Cristo para o cristianismo. Estar acorrentado, mas vivo, é ainda ter garantida a possibilidade de "reverter à eternidade" como era o desejo de Herói.

Assim como Édipo - que desafiou os desígnios do oráculo e cometeu um crime contra o pai e a mãe - Herói igualmente desobedece ao desejo do Progenitor, o desígnio de vida. Por isso, também fica cego e tem a assistência
42 Nas primeiras páginas de $O$ Anjo, há o relato da quase expulsão de Herói do colégio marista, por ele ter defendido a liberdade de suicídio.

43 O Anjo, p. 248. 
44 Poesia completa,

p. 209

45 Mendes, Murilo. Re-

cordação de Ismael

Nery (Ix). O Estado de

São Paulo, São Paulo,

II.9.I948. não de Antígona, mas da enfermeirinha do hospital, que ele julga ser a BemAmada.

No poema "Uma coisa vos digo". de Tempo e eternidade, obra contemporânea a $O$ Anjo, lê-se:

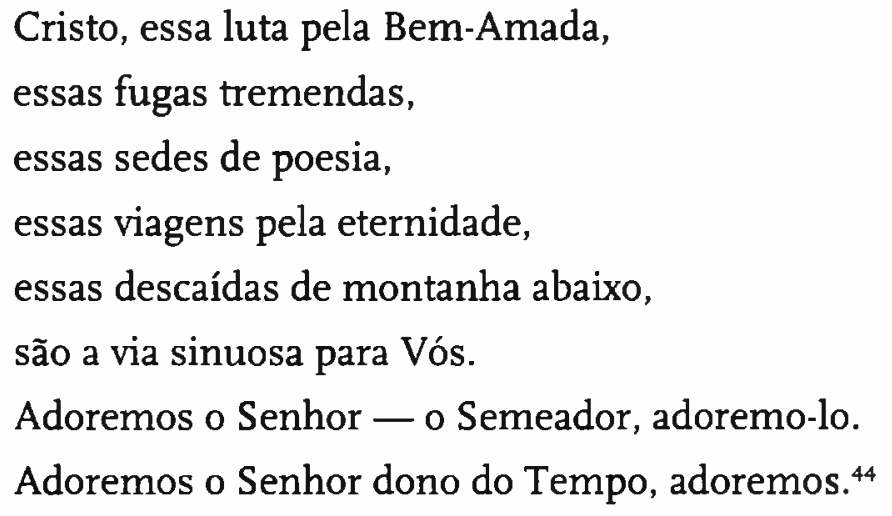

Tal qual se diz nesses versos, os caminhos sinuosos de Herói - a decadência pessoal e social, a inadequação, a busca de um ideal feminino inalcançável, a tentativa de suicídio, a mutilação - levam todos a Deus, todos "revertem à eternidade"

Prometeu, Édipo e Herói representam um só destino: a aventura humana iniciada por Adão de sempre querer saber mais, de querer ser livre para decidir. Para isso é necessário desobedecer e, posteriormente, suportar o peso dos próprios gestos.

Fazendo referência ao episódio bíblico em que Verônica limpa o sangue de Cristo quando este sobe o calvário, Herói chama-se de "lenço sujo de Cristo" por se identificar com a divindade. Seria uma espécie de cópia imperfeita do símbolo maior do sofrimento humano. Essa identificação garante a universalidade da personagem, que representa a própria condição humana em todos os tempos, seja entre os gregos, seja à época de Cristo, seja na era contemporânea.

A idéia de homem-síntese, "coágulo" de gerações passadas, é outro traço da teoria essencialista que identificamos na ficção de Jorge de Lima. Murilo Mendes, comentando as idéias de Ismael Nery, afirma:

Ele se sentia afim com todos os homens, dizendo sempre que tinha um pedacinho de cada um. Porque todos provêm de um único germe, desenvolvido e desdobrado através dos tempos. Acreditava firmemente no dogma da unidade espiritual do gênero humano. ${ }^{45}$ 
Espécie de compósito das várias experiências humanas realizadas por sucessivas gerações, o homem contemporâneo, mesmo sem ter consciência disso, guarda em si todos os conhecimentos, os pecados e as virtudes de sua espécie. Por isso, embora de gestos individualistas, o homem moderno deve buscar, na visão essencialista, a consciência de sua unidade, por meio da abstração do tempo e do espaço.

Não é de estranhar, portanto, que o ser humano sinta em seu interior contradições, desdobramentos ou a coexistência de vários seres.

Murilo Mendes assim depõe sobre os vários seres que habitavam o interior de Ismael Nery: "Não havia dois homens em Ismael: havia muitos homens que se disputavam o primeiro lugar no drama que ele representava." 46

O próprio Ismael Nery, no poema "Oração de I.N." (I933), trata dessa questão:

Meu Deus, para que pusestes tantas almas num só corpo?

Neste corpo neutro que não representa nada do que sou [...]

Dai-me, como vós tendes, o poder de criar corpos para as minhas almas ${ }^{47}$

As idéias desse poema não são diferentes das manifestadas pelo narrador-personagem de A mulher obscura neste trecho: "Sinto que ando com os pés de criaturas que caminharam até a coagulação do momento que eu sou"

Além disso, esse conceito essencialista reforça o ponto de vista de que os protagonistas da ficção de Jorge de Lima alegoricamente representam a condição humana, vista pela perspectiva judaico-cristã.

\section{Um anjo acorrentado no tempo}

É notório o interesse de Jorge de Lima em abstrair a noção de tempo e espaço na sua ficção, como meio tanto de conferir universalidade às suas personagens e às suas obras quanto de remetê-las ao tempo mítico. Contudo, os planos ideológico e estético dessa ficção se contradizem: as obras trazem inúmeras marcas de temporalidade. Mesmo aspirando à atemporalidade, a ficção de Jorge de Lima é uma espécie de mosaico das grandes tendências da prosa e da vida cultural brasileiras verificadas entre os anos 1920 e 1940.

Semelhantemente à figura que dá nome à sua primeira obra de ficção aqui considerada - O Anjo - , cuja natureza é ao mesmo tempo celeste e terres-
46 mendes, Murilo. Recordação de Ismael Nery (vi). O Estado de São Paulo, São Paulo, 6.8.1948. 47 A Ordem (Rio de Janeiro), fevereiro/ 1935 , p. 89 . 
48 Assim comenta Jorge Amado: "Não sei se houve qualquer espécie de intenção política em Jorge de Lima ao escrever Calunga. Mas sem dúvida ele não agradará muito àqueles que vivem hoje, quase histericamente, clamando pelo romance de reação ao social e ao local. Não é um romance revolucionário. Quando termina o livro não se enxerga nenhum caminho. Ficou somente a água. Mas é o romance da miséria daqueles todos que moram ali. Social, local, mas profundamente humano e universal" (Apud Edson Luís. História crítica da poesia brasileira. Rio de Janeiro: Ariel, I935, p. 260). tre, humana e animal, a prosa de Jorge de Lima se caracteriza pela dubiedade: ela ora está presa ao mito, ora ao mundo temporalizado dos homens.

A despeito de sua posição contrária ao engajamento ideológico da literatura dos anos I930, sua obra se mostra profundamente comprometida com a pregação dos ideais católicos, o que em essência - consideradas as diferenças ideológicas, é claro - não difere da pregação socialista de vários romancistas da época.

E, se se consideram as relações entre engajamento político-ideológico e representação da realidade em literatura, o que se nota na ficção de Jorge de Lima, principalmente em seu último romance, é que a pregação religiosa beira o proselitismo que marcava, por exemplo, os romances de Jorge Amado da fase proletária.

Jorge Amado criticou em Calunga a ausência de uma direção política clara para os oprimidos..$^{8}$ De fato, não era essa a intenção do autor já que a única direção que podia dar à sua obra era a de essência cristã. Apesar disso, guardadas as diferenças ideológicas, os dois autores se mostram igualmente empenhados em uma causa.

Talvez Jorge de Lima não tenha alçado vôos tão altos em sua ficção quanto em certa parte de sua poesia. Contudo, é autor de uma prosa significativa, que merece um lugar próprio em nossa literatura, principalmente por causa dos rumos quase únicos que tomou.

Narrando a história do homem moderno, Jorge de Lima narra também a história do homem de todos os tempos. Por meio da glosa e da alegoria, reconta sucessivas vezes a narrativa do homem original como forma de reatar o fio da história humana.

A queda é uma quebra. A quebra da inocência, que corresponde à inconsciência, ao não-saber. Na visão do autor, o homem, em sua ânsia inesgotável de conhecimento, afastou-se de sua própria origem transcendente e busca sempre regressar. Jorge de Lima, escritor, artesão das palavras, procura, com sua ficção, recompor o fio partido a fim de contar uma nova história da humanidade.

Como Prometeu, Jorge de Lima anuncia o nascimento de uma nova civilização, de um homem novo, feito de "barro diferente" Com suas palavras de fogo, que pregam a abstração do tempo como forma de imersão no tempo mítico, mostra-se, contudo, completamente aprisionado no próprio tempo.

William Cereja é autor de Literatura Brasileira [Saraiva/Atual] e Texto e interação [Saraiva/Atual]. É doutorando no LAEL da PUC-SP. 


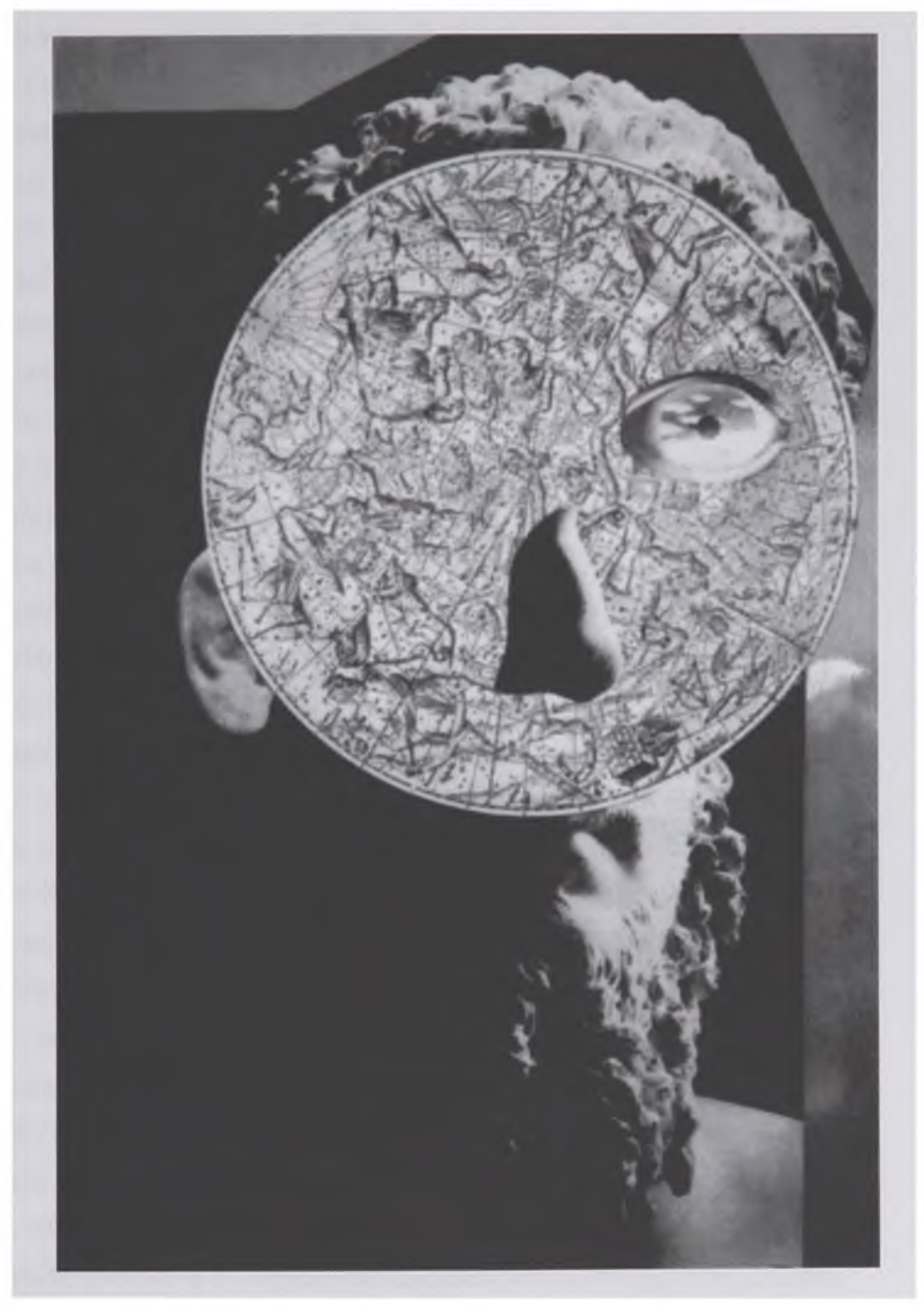

